\title{
CONTRASTIVE ANALYSIS OF FRENCH AND NUBIAN: NOUN PHRASE CONSTRUCTIONS
}

\section{Ruhan Güçlü ${ }^{1}$}

\begin{tabular}{|c|c|}
\hline Article Info & Abstract \\
\hline DOI: 10.35452/caless.2020.28 & \multirow{12}{*}{$\begin{array}{l}\text { This study aims to reveal the similarities and differences between French and } \\
\text { Nubian languages regarding the internal structure of their noun phrases and the } \\
\text { order of the constituents in their simple and complex noun phrases. To this end, } \\
\text { the contrastive analysis (CA) is applied which is composed of three steps as (1) } \\
\text { description; (2) juxtaposition; (3) comparison. The contrastive analysis in this } \\
\text { study shows that French and Nubian languages have many differences } \\
\text { regarding the placement of a head noun, the placement of an adjective of size } \\
\text { and quality, the placement of numerals and the case marker in a complex noun } \\
\text { phrase and share fewer similarities such that both languages can use two } \\
\text { adjectives successively in a complex noun phrase. The findings of this study } \\
\text { contribute to comparative historical linguistics to establish language genealogy, } \\
\text { to typological linguistics to create language taxonomies, to translation studies to } \\
\text { investigate problems of equivalence in creating bilingual dictionaries. }\end{array}$} \\
\hline Keywords & \\
\hline Contrastive Analysis & \\
\hline Noun Phrase Constructions & \\
\hline French Language & \\
\hline Nubian Language & \\
\hline Simple and Complex Noun & \\
\hline Phrases & \\
\hline Received: 18.09 .2020 & \\
\hline Accepted: 29.11.2020 & \\
\hline & \\
\hline & \\
\hline
\end{tabular}

\section{FRANSIZCA VE NÜBYENIN KARŞITSAL ÇÖZÜMLEMESİ: AD ÖBEĞİ} YAPILARI

\begin{tabular}{|c|c|}
\hline Makale Bilgisi & Özet \\
\hline DOI: 10.35452/caless.2020.28 & \multirow{11}{*}{$\begin{array}{l}\text { Bu çalışma, Fransızca ve Nübye dillerindeki ad öbeklerinin iç yapısı ve } \\
\text { bileşenlerin basit ve karmaşık ad öbeklerindeki sırası açısından benzerlik ve } \\
\text { farklılıkları ortaya koymayı amaçlamaktadır. Bu amaçla, (1) tanımlama; (2)yan } \\
\text { yana koyma ve (3) karşılaştırma olarak üç adımdan oluşan karşıtsal çözümleme } \\
\text { (CA) uygulanır. Bu çalışmada yapılan karşıtsal çözümleme, Fransızca ve Nübye } \\
\text { dilleri arasında bir baş ismin yerleştirilmesi, büyüklük ve nitelik sıfatının } \\
\text { yerleştirilmesi, sayıların yerleştirilmesi ve karmaşık ad öbeğindeki durum } \\
\text { işaretçisi açısından pek çok farklılık olduğunu, her iki dilin karmaşık ad } \\
\text { öbeğinde art arda iki sıfatın bulunması açısından ise daha az benzerliği } \\
\text { paylaştığını göstermektedir. Bu çalışmanın bulguları, dil soy bilimi oluşturmak } \\
\text { için karşılaştırmalı tarihsel dilbilime, dil sınıflamaları oluşturmak için tipolojik } \\
\text { dilbilime, iki dilli sözlükler oluşturmak için denklik problemlerini araştıran } \\
\text { çeviri çalışmalarına katkıda bulunmaktadır. }\end{array}$} \\
\hline Anahtar Kelimeler & \\
\hline Karşıtsal Çözümleme & \\
\hline Ad Öbeği Yapıları & \\
\hline Fransizca & \\
\hline Nübye & \\
\hline Basit ve Karmaşık Ad & \\
\hline Öbekleri & \\
\hline Gönderim Tarihi: 18.09.2020 & \\
\hline Kabul Tarihi: & \\
\hline Yayın Tarihi: 30.11 .2020 & \\
\hline
\end{tabular}

Cited as APA: Güçlü, R. (2020). Contrastive analysis of French and Nubian: noun phrase constructions. International Journal of Current Approaches in Language, Education and Social Sciences (CALESS), 2(2), 528-546.

APA'ya göre alıntılama: Güçlü, R. (2020). Fransızca ve Nübyenin karşıtsal çözümlemesi: ad öbeği yapıları. Uluslararası Dil, Eğitim ve Sosyal Bilimlerde Güncel Yaklaşımlar Dergisi (CALESS), 2(2), 528-546. 


\section{Introduction}

\subsection{Contrastive Analysis}

Contrastive analysis is an area of comparative linguistics which is concerned with the comparison of two languages to determine the differences or similarities between them, either for theoretical purposes or purposes external to the analysis itself. It implies a belief in language universals; if there were no features in common, there would be no basis for comparison. Fries (1945), Weinreich (1953) and Lado (1957) are precursors in the studies on Contrastive Analysis (CA). In his preparation of teaching materials at the English Language Institute of the University of Michigan, the applied linguist Fries (1945:9) proposed with the following statement which illustrates that efficient language teaching materials could be produced by obtaining a scientific description of the target language through its careful comparison with a similar description of the learner's first language:

The most effective materials are those that are based upon a scientific description of the language to be learned, carefully compared with a parallel description of the native language of the learner (in Bada, 2001).

In parallel with Fries' statement, Krzeszowski (1990: 35) asserts that no comparison is possible without a prior description of the elements to be compared and all contrastive studies must be founded on independent descriptions of the relevant items of the languages to be compared. This is the first step of contrastive analysis. The second step is the juxtaposition of the described patterns in these languages which enables to decide what is to be compared with what and to whether or not element $X$ in one language is equivalent with element $Y$ in another language (Krzeszowski, 1990:35). In the last step of the contrastive analysis, the similarities and differences existing between two languages are identified and presented.

\subsection{Literature Review}

The contrastive analysis first started in the 1940s by Charles Fries, then underwent a period of rapid development with the first systematic and extensive formulation proposed by Robert Lado in 1957. Using structuralist linguistic methods, Lado set out procedures for the comparison of phonology, grammar and vocabulary with the general assumption that contrasting two languages would help predict the features that would represent difficulty or ease in learning a second language due to realizing the differences and similarities between the first and the second language and discussed ways in which such analyses might be relevant to syllabus and materials design, methodology and testing. 
Another active area in the 1960s was the empirical study of language universals using CA to categorize languages by structural similarities and differences. Throughout the 1970s and 1980s, however, the contrastive analysis was extensively practiced in various European countries, particularly in Eastern European countries, The extension of CA continued with the interests in Chomskyan linguistics in which contrastive pragmatics is based on the statements of universal principles (Thomas, 1983) and contrastive rhetoric hypothesis which proposes that "different speech communities have different ways of organizing ideas in writing" (Chen, 1997) and in the early 1990s, there were clear signs of a renewed interest. Since then, the rapid development of automatic data processing and information technology as opened up new prospects for contrastive approaches through the potential of large corpora.

With the increasing interest in teaching foreign languages in the USA after the Second World War, the structural linguistics was concerned with comparing and contrasting different language systems dates back the end of the nineteenth century (James, 1981) and believed that pointing to the similarities of the two languages compared will make the process of foreign language learning easier for the learner.

\subsubsection{Some previous studies with contrastive analysis}

Since 20th century, many studies are conducted comparing and contrasting the languages regarding many features as contrastive linguistics embraces all the major levels of linguistics such as phonology, semantics, syntax and pragmatics in text studies and with some sociolinguistic and psycholinguistic perspective. Some contrastive studies regarding French language and Nubian language are given below. In their contrastive analysis of English and French present progressive constructions in the semantic dimension, De Wit and colleagues (2013) investigated their presentday uses and their diachronic evolution. The analysis of data showed that both constructions are frequently used in contemporary English and French to stress the atypical nature of situations. On the other hand, Walid (2012) compared and contrasted English and French phonological systems with a theoretically oriented corpus. It provides a general characterization of the structure of the phonological system in each language with reference to the standard accents in England and France. N'Gom (1997) aimed to do a systematic comparison of the French and Mandinka phonological systems to ascertain their phonetic and phonological differences and to predict difficulties. Wijdan Mohi Eldeen (2007) contrasted Nubian and English languages from the morphological perspective with the data obtained by interview and meetings to identify the similarities and dissimilarities between Nubian and English at the level of morphology, to clarify the confusion of the terms dialect and 
language, as far as the Nubian language is concerned and to increase the existing knowledge about the morphology of Nubian as a contribution to relevant studies and found both similarities and differences regarding the morphological structure of these languages. The other study shows the contrastive mode of the Yoruba vowel and consonants as compared with that of the French language. The study reveals that vowel and consonant sounds in the Yoruba language are always tonal and it is often accompanied by the melodic register which has a harmonious and vocalic mechanism for oral expression (Odudigbo, 2014).

Last but not least, the study which investigates the Nubian language is Al Faki's study (2014). The study focused on analyzing and contrasting sentence construction in both Nubian and English languages and revealed that both languages share some similarities in terms of constructing sentences such as; using coordination to construct compound and complex sentences; having equivalent conjunctions; having equivalent pronouns to construct (WH) questions, having ellipsis whereas the differences between them appear regarding having different syntactic order of elements in sentence construction.

During the last twenty years research on the internal structure of noun phrases has been to a great extent inspired by the assumption that the basic structure of such phrases is part of universal grammar. According to Payne (2006), "noun phrases are traditionally thought of as consisting minimally of a head noun, together with any number of noun phrase modifiers" such as an adjective, numeral, quantifier, determiner, possessive adjective, genitive, and/or a relative clause. Although the noun phrase requires a certain element, such as the noun, to distinguish it from other phrases, there is no limit on the number of words or constituents that can be used to make a noun phrase. The internal structure and the order of the constituents in a noun phrase may change from language to language.

\subsection{French and Nubian Languages}

French and Nubian languages belong to different language families. The French language belongs to the Romance branch of the Indo-European language family. Like all Romance languages, it descended from the Vulgar Latin of the Roman Empire between the third and eighth centuries. On the other hand, Nubian language belongs to the Nubian languages branch of the Eastern Sudanic languages. The Nubian languages which are spoken in Sudan and southern Egypt especially along the banks of the Nile River are now considered to be a part of the Nilo-Saharan language family. 


\subsection{Research Questions}

This paper aims to analyze the internal structure of French and Nubian simple and complex noun phrases and the order of their constituents and to reveal the differences and similarities between these languages. In parallel to this aim, the study attempts to answer the following research questions:

- How Nubian and French languages differ from each other regarding the internal structure of simple noun phrase and the order of their constituents?

- How Nubian and French complex noun phrases differ from each other regarding the order of their constituents?

\subsection{Scope and Significance of the Study}

There is limited research in the literature comparing the Nubian language and French with other languages. Most of the previous studies on the Nubian language and French language focused more on phonology and grammar. The researcher is encouraged to fill the gap by studying the similarities and differences between the Nubian and French languages regarding noun phrase construction.

The researcher believes that this study has a theoretical significance to researchers since it deals with one aspect of grammar and hopes that the investigation will contribute to the understanding and use of other Sudanese languages. This kind of contrastive study may be helpful in revealing the areas of difficulty in the learning of a second language and teaching French as a foreign language to Nubian learners by Nubian teachers taking into consideration the contrastive analysis hypothesis (CAH) which claims that the principal barrier to second language learning is the interference of the first language system with the second language system, in turn, would enable linguists and language teachers to predict the difficulties a learner would encounter. This can be summarized like this:

Difference b/w L1 \& L2 item $\rightarrow$ interference of L1 into L2 $\rightarrow$ difficulty in learning L2

The logical conclusion from this formula was that second language learning basically involved the overcoming of the differences between the two linguistic systems, the native and the target languages.

Since both languages are of different descents and are spoken in different places of the world and have different alphabets and are from morphologically different families, they are expected to have less similar and many different linguistic features. Overall, 
this study is expected to shed light on the difficulties that may arise when learning the noun phrase constructions in such distantly related languages.

\section{Method}

Contrastive analysis is composed of three steps: (1) description; (2) juxtaposition; (3) comparison (Halliday et al., 1964 in Krzeszowski, 1990: 35). In this study, description of noun phrase constructions in two languages are given as Krzeszowski (1990: 35) asserts that no comparison is possible without a prior description of the elements to be compared and all contrastive studies must be founded on independent descriptions of the relevant items of the languages to be compared. The second step is the juxtaposition of the word stress patterns in these languages which enables to decide what is to be compared with what and to whether or not element $X$ in one language is equivalent with element $Y$ in another language (Krzeszowski, 1990:35). In the last step of the contrastive analysis, the similarities and differences existing between two languages are identified and presented.

As for the data source, all examples and data from French and Nubian languages used in this comparative study have been taken from published sources. All examples provided in this study are sourced from those published in Alamin (2014), Bouveret and Legallois (2012), Hamel (1925), Lodge and colleagues (2016), Salim (1991), Rowlet (2007), Sallee and Hebert (2014), Siméus (2017), Vaillant (2016).

\section{Data Analysis and Findings}

\subsection{Noun Phrases in Nubian Language}

In Nubian language, noun phrases can be represented by a noun with or without modifiers. Both categories are given successively below. Later on, complex NP structures in Nubian language are given.

\subsubsection{NPS represented by a personal pronoun, determiner, quantifier or a bare noun}

(1) Nubian

$\begin{array}{lclc}\text { ay } & \text { na } & \text { say-re } & k \partial l-m \\ \text { 1SG } & \text { 3SG } & \text { morning-LOC } & \text { see-PST.3SG }\end{array}$

'I saw him in the morning'

(2) Nubian
in-gi
sunde
DET-ACC
SMELL.IMP.2SG 
'smell this'

(3) Nubian
weeri taa-s-a
some come-PST-3PL
'some came'

(4) Nubian

elum essi-r da

crocodile river-LOC exist.3SG

'the crocodile is at the river'

Examples (1), (2), (3) and (4) represent a type of NP that includes personal pronouns, determiners, quantifiers and a bare noun successively. This type of NP is referred to as minimal NP. Fedden (2011) explains that "a minimal noun phrase consists of a bare noun" and can appear as a single noun without modifiers.

\subsubsection{NPS represented by a noun with modifiers}

This type of NP involves a noun with nominal modifiers. These modifiers in Nubian languages can involve possessive adjectives, determiners, adjectivals, numerals, quantifiers and another noun in a genitive construction.

\subsubsection{Possessive adjective + noun .}

The examples below show the position of possessive adjectives in the NP in Nubian languages. They are always placed before the head noun.

(5) Nubian

$$
\begin{array}{ll}
\text { ayiin } & \text { noog } \\
\text { 1SG.GEN } & \text { house } \\
\text { 'my house' } &
\end{array}
$$

The rule is $\mathbf{N P} \rightarrow$ personal pronoun + genitive linker $-\mathbf{n}+$ noun

Alamin (2014) claims that across the Nubian languages, the possessor is consistently marked by the genitive linker and it precedes the possessed. It has been found that it is also possible for the possessive adjective to follow the head noun in the NP, as shown in example (6). 
(6) Nubian

noog anni

house 1SG.GEN

'my house'

Moreover, there is a number agreement between the possessive adjective and the head noun.

(7)Nubian

noog-ri anni-ri

house-PL 1SG.GEN-PL

'my houses'

\subsubsection{Determiner + noun.}

In Nubian, determiners precede the head noun in an NP, as seen in the following example.

(8) Nubian

in id

DET.SG man

'this man'

The rule is $\mathbf{N P} \rightarrow$ determiner + noun

3.1.2.3. Noun + adjective/ adjective + noun .

In Nubian, adjectives generally occur after the head noun they modify.

(9) Nubian

id adel

man good

'the good man'

The rule is $\mathbf{N P} \rightarrow$ noun + adjective.

It has been found in the Midob data that the adjective precedes the head noun.

The rule is $\mathbf{N P} \rightarrow$ determiner + adjective + noun .

(10) Nubian

nen tiinin acci

DET.SG dead donkey

'this dead donkey' 


\subsubsection{Noun + numeral.}

Numerals in Nubian follow the head noun as shown in the example below.

(11) Nubian

$$
\begin{aligned}
& \text { Kitab wer } \\
& \text { book one } \\
& \text { 'one book' }
\end{aligned}
$$

The rule for this np construction is: $\mathbf{N P} \rightarrow$ noun + numeral.

When the numeral refers to several entities the head noun is not marked for plural, as illustrated in the example below.

(12) Nubian

$$
\begin{aligned}
& \text { id owwi } \\
& \text { man two } \\
& \text { 'two men' }
\end{aligned}
$$

\subsubsection{Noun + quantifier.}

Nubian quantifiers always follow the head noun as in the example below.

(13) Nubian

$$
\begin{aligned}
& \text { burw-i digri } \\
& \text { girl-PL many } \\
& \text { 'many girls' }
\end{aligned}
$$

The rule is $\mathbf{N P} \rightarrow$ noun + quantifier

\subsubsection{Genitive construction.}

Concerning the genitive, Nubian always employs the genitive linker -n. It links two nouns; the first noun having the role of the possessor and the second one having the role of possessed (Alamin, 2014). Thus, the genitive in Nubian precedes the head noun of the NP as in the following example:

(14) Nubian

$$
\begin{aligned}
& \text { ee- } n \text { agil } \\
& \text { woman-GEN mouth } \\
& \text { 'the woman's mouth' }
\end{aligned}
$$

The rule is NP $\rightarrow$ possessor + genitive linker + possessed 


\subsubsection{Complex NP constructions}

The Nubian NPS can be complex when they consist of more than one modifier, as illustrated in the examples below.

(15) Nubian

id doro gele kemis
man fat red four
'four fat red men'

The rule is NP $\rightarrow$ noun + adjective of size + adjective of color + numeral

(16) Nubian

wel mushindili owwi
dog ugly two
'two ugly dogs'

The rule is $\mathbf{N P} \rightarrow$ noun + adjective + numeral

(17) Nubian
in hage-gi wart-e
DET.SG maize-ACC cut-IMP.2SG
'please cut this maize'

The rule is $\mathbf{N P} \rightarrow$ determiner + noun + case marker

(18) Nubian

$\begin{array}{lll}\text { buru } & \text { geele-gi } & \text { nall-e } \\ \text { girl } & \text { red-ACC } & \text { look.at-IMP.2SG }\end{array}$

'please look at the red girl'

The rule is $\mathbf{N P} \rightarrow$ noun + adjective + case marker

(19) Nubian

$\begin{array}{lcllc}\text { Ay } & \text { wilid } & \text { kuduud } & \text { uus-ka } & n a-s \\ \text { 1SG } & \text { boy } & \text { little } & \text { bad-ACC } & \text { see-PST.1SG }\end{array}$

'I saw the bad little boy'

The rule is NP $\rightarrow$ noun + adjective of size + adjective of quality+ case marker

(20) Nubian

$\begin{array}{lllll}\varepsilon n \varepsilon & \text { faald } & \text { wate } & \text { oro } & k \varepsilon n r \varepsilon \\ \text { DET.SG } & \text { house.SG } & \text { big } & \text { two } & \text { are.nice }\end{array}$

'these two big house are nice'

The rule is NP $\rightarrow$ determiner+ noun + adjective of size + number.

(21) Nubian

aanyir keel keeci-re ad konnyiyum 
people red grass-INS house build.PRS.3PL

'people build the house with red grass'

The rule is $\mathbf{N P} \rightarrow$ adjective + noun + case marker.

According to the complex construction of NPs in Nubian, there is some evidence that noun precedes the other constituents; adjectival modifiers expressing size precede adjectival modifiers expressing quality or color (15 and 19). Moreover, numerals always occur at the end of the NP as in examples (15), (16), and (20). Case marker is also placed at the last element of the NP as in the examples (17), (18), (19) and (21).

\subsection{Noun Phrases in the French Language}

In the French language, noun phrases can be represented by a noun with or without modifiers. Both categories are given successively below. Later on, complex NP structures of the French language are given.

\subsubsection{NPS represented by a proper noun}

As a single noun, French accepts only proper names as a noun phrase (Salim, 1991).

(22) Jean, Pierre, Paris, etc., may occur alone as noun phrases because each stands for 'proper name'.

The rule is $\mathbf{N P} \rightarrow$ pn

\subsubsection{NPS represented by a noun with modifiers}

This type of NP involves a noun with nominal modifiers. These modifiers in the French language can involve possessive adjectives, determiners, adjectivals, numerals, quantifiers and genitive construction.

3.2.2.1. Possessive adjective + noun.

French possessive adjectives in the NP are always placed before the head noun.

(22) French

Ma maison

POSS.1SG>SG.f house(f)

'my house' 
There is a number agreement between the possessive adjective and the head noun.

(23) French

Ses maisons

POSS.3SG >PL house(F).PL

‘his/her houses'

\subsubsection{Determiner +noun.}

The most common constituents that accompany a noun in French in a two elements noun phrase are noun specifiers. These are determiners (Salim, 1991).

(24) French

Le $\quad$ livere

DET.SG.m $\operatorname{book}(\mathrm{m})$

'the book'

The rule is $\mathbf{N P} \rightarrow$ determiner + noun

Jones (1996) says that "in French, all NPs must contain a determiner."

3.2.2.3 Noun+adjective/adjective+noun.

In French, adjectivals may precede or follow the head noun they modify as shown in the examples (26) and (27) successively.

(25) French

La tableau rouge

DET.SG.(f) painting red

'the red painting'

The rule is $\mathbf{N P} \rightarrow$ determiner + adjectival + noun

(26) French

Le joli tableau

DET.SG.(m) beautiful red

'the beautiful painting'

The rule is $\mathbf{N P} \rightarrow$ determiner + noun +adjectival

3.2.2.4 Numeral+noun. 
Numerals in French precede the head noun as shown in the example below.

(27) French

$$
\begin{aligned}
& \text { un livre } \\
& \text { one.(m) } \operatorname{book}(\mathrm{m}) \\
& \text { 'one book' }
\end{aligned}
$$

The rule is $\mathbf{N P} \rightarrow$ number + noun

In some circumstances, the determiner and the numeral can appear in the same noun phrase.

(28) French

les deux livres

DET.PL two book.PL

'the two books'

The rule is $\mathbf{N P} \rightarrow$ determiner + number + noun

There is a number agreement between the adjectival and the head noun.

(29) French

$\begin{array}{llll}\text { une plage intéressante } & \text { des plages intéressantes } \\ \text { one.SG.(f) beach interesting.(f) } & \text { DET.PL beach.PL interesting.PL } \\ \text { 'an interesting beach' } & \text { 'the interesting beaches' }\end{array}$

The rule is $\mathbf{N P} \rightarrow$ determiner+ noun + adjectival

\subsubsection{Quantifier+noun.}

French quantifiers always precede the head noun as in the example below.

(31)French

quelques filles

some.PL girl-PL

'some girls'

The rule is $\mathbf{N P} \rightarrow$ quantifier + noun

3.2.2.6 Genitive construction.

Because of the loss of morphological case inflection in French (Carlier et al., 2013), there is no genitive marker in French. When two nouns come together, denoting different 
persons or things, the second is carrying the possessive meaning and as Vaillant (2016) says it is expressed by the preposition ' $\mathrm{de}^{\prime}$.

(32) French

le livre de Pierre

DET.(m) book GEN. Pierre

'Pierre's book'

The rule is NP $\rightarrow$ determiner + possessed + de(genitive) + possessor.

The function of de in phrases like (32) is to assign case to the noun phrase as Jones explains (1996:220).

\subsection{Complex NP constructions}

The French NPs can be complex when they consist of more than one modifier, as illustrated in the examples below.

(33) French

la petite fille intelligente

DET.SG.(f). little.(f) girl.SG intelligent.(f)

'the little intelligent girl'

The rule is NP $\rightarrow$ determiner + adjective of size + noun + adjective of quality

Salim (1991) explains that French puts the first adjective before the noun and the second after the noun. In their study, Lodge and colleagues (2016) explain that in French it is also possible in a noun phrase that it can have more than one adjective in succession, as in the example (34).

(34) French

la belle petite fille

DET.SG.(f). beautiful.(f). little.(f). girl.SG

'the little beautiful girl'

The rule is $\mathbf{N P} \rightarrow$ determiner+ adjective of quality+ adjective of size+ noun

French also elects to use the conjunction et 'and' between the adjectivals (Salim, 1991).

(35)French

Un chien dangeureux et mauvais

DET.SG.(m) dog.SG.(m). dangerous.(m) and bad.(m)

'a dangerous and bad dog' 
(36) French

Deux filles intelligentes

two girl.PL intelligent.PL(f).

'two intelligent girls'

The rule is $\mathbf{N P} \rightarrow$ numeral + noun +adjectival

(37)French

Les gardes du roi

DET.PL guards of king

'the king's guards'

The rule is NP $\rightarrow$ determiner + noun + case marker (genitive) + noun.

According to the complex construction of NPs in French, adjectival modifiers may follow or precede the head noun; the head noun is always preceded by a determiner, numeral or adjectival modifiers; head noun may occur as a last or middle element in an NP; adjective of size always precede the head noun while adjective of quality can appear before or after the head noun in the arrow as in the examples (33) and (34); numerals always precede the head noun in the NP. Case marker is always placed between the possessor and the possessed nouns in the NP as in the examples (32) and (37).

\subsection{Contrastive analysis of French and Nubian}

This study attempts to contrastively analyze the French and Nubian languages regarding their noun phrase constructions. The ultimate objective is to find out the similarities and differences between the two languages at the phrase level. The analysis reveals that both Nubian and French languages have aspects of similarities and differences as far as noun phrase construction is concerned. Contrastive analysis of simple French and Nubian noun phrases regarding their internal structure and order of their constituents is as follows:

- Both Nubian and French languages have a minimal noun phrase. However, while a noun can stand alone in Nubian languages when it is a personal pronoun, determiner, quantifier or a bare noun, in the French language a noun can stand alone only when it is a proper name.

- In Nubian language, possessive adjectives may precede or follow the head noun while they are always placed before the head noun in French.

- In a Nubian noun phrase which consists of a possessive adjective and a noun, there is a genitive linker attached to the possessive adjective while in French 
there is no genitive marker. The possessive meaning is expressed by the preposition "de" in French.

- In both languages, there is a number agreement between the possessive adjective and the head noun in an NP.

- In both languages, determiners precede the head noun in an NP.

- In French, all nouns except proper nouns must be preceded by a determiner. This can be an article, a possessive adjective, a demonstrative adjective, a quantifying adjective, and interrogative adjective or a numeral. However, in Nubian languages, NP can stand alone as a bare noun without any modifier.

- In both languages, the adjective may precede or follow the noun in a noun phrase.

- In Nubian languages, numerals follow the head noun while French numerals precede the head noun in an NP.

- When the numeral refers to several entities, the head noun is not marked for plural in Nubian languages while in French head noun is marked for plural.

- French quantifiers always precede the head noun while Nubian quantifiers occur after the head noun they modify.

- There is number agreement between the adjectival and the head noun in French while there is no number agreement in Nubian languages.

- The genitive in Nubian precedes the head noun of the NP while in French it follows the head noun.

Contrastive analysis of complex French and Nubian noun phrases in regard to the ordering of their constituents is as follows:

- In Nubian complex construction of NPs, noun precedes the other constituents while in French complex construction of NPs head noun is always preceded by a determiner, numeral or adjectival modifiers and head noun may occur as a last or middle element in an NP.

- Nubian adjectival modifiers expressing size precede adjectival modifiers expressing quality while adjectival modifiers in French NPs may follow or precede the head noun and adjective of size always precede the head noun while adjective of quality can appear before or after the head noun.

- Nubian numerals always occur at the end of the NP while numerals in French always precede the head noun in the NP. 
- Nubian case marker is placed at the last element of the NP while French case marker is always placed between the possessor and the possessed nouns in the NP.

- Both Nubian and French languages can use two adjectives successively without a linking element. However, French can also put the first adjective before the head noun and the second after the noun.

\section{Discussion and Conclusion}

From the above comparison of the Nubian noun phrase and the French noun phrase, it can be concluded that both languages share a lesser degree of similarities and more of differences regarding both the internal structure of the noun phrases and order of the constituents in the simple and complex noun phrase.

The comparative analysis reveals that French and Nubian languages have both common points and differences in terms of the placement of a possessive adjective, a determiner and an adjectival in a simple noun phrase. Specifically, possessive adjectives may precede or follow the head noun while they are always placed before the head noun in French. In addition, determiners precede the head noun in a noun phrase in both languages and the adjective may precede or follow the noun in a noun phrase in both languages. On the other hand, these languages, without any expectations, differ from each other regarding the placement of numerals, quantifiers and genitive in a simple noun phrase. Specifically, the numerals in the Nubian languages follow the head noun while French numerals precede the head noun in an NP. The quantifiers in French always precede the head noun while Nubian quantifiers occur after the head noun they modify. The genitive in Nubian precedes the head noun of the NP while in French it follows the head noun. In terms of the ordering of the constituents in French and Nubian complex noun phrase, the analysis shows many differences existing between these languages regarding the placement of a head noun, the placement of an adjective of size and quality, the placement of numerals and the case marker in a complex noun phrase. Specifically, in the Nubian complex construction of NPs, noun precedes the other constituents while in French complex construction of NPs a head noun is always preceded by a determiner, numeral or adjectival modifiers and a head noun may occur as a last or middle element in an NP. When it comes to the placement of an adjective of size and adjective of quality, in a Nubian noun phrase, the adjective of size is followed by an adjective of quality while it can be vice versa in a French noun phrase. Nubian numerals and case marker always occur at the end of a noun phrase while numerals in French always precede the head noun in the noun phrase and the French case marker is always placed between the 
possessor and the possessed nouns in the noun phrase. These languages share less similarities regarding the ordering of the constituents in their complex noun phrases such as that both languages can use two adjectives successively in a complex noun phrase.

Consequently, this study provides both a theoretical and practical basis which help teachers of either French or Nubian languages overcome first language interference problems by illustrating linguistic differences between the two languages concerning noun phrase constructions. As CA provides a detailed linguistic analysis on the languages, the learners of the languages may get benefit from this field with a better understanding of their structural properties. This study might help the learners of French and Nubian languages and also may be applied to the field of translation.

\section{References}

Alamin, S. (2014). Noun phrase constructions in Nubian languages: A comparative study. Dotawo: A Journal of Nubian Studies, 1(10), 203-220.

Alfaki, I. M. (2014). A contrastive study in sentence construction between English and Nubian Languages. American International Journal of Contemporary Research, 4(5), 137-147.

Bada, E. (2001). Native language influence on the production of English sounds by Japanese learners. The Reading Matrix, 1(2), 1-15.

Bouveret, M., \& Legallois, D. (Eds.). (2012). Constructions in French (pp.9). Amsterdam/Philadelphia: John Benjamins Publishing Company.

De Wit, A., Patard, A., \& Brisard, F. (2013). A contrastive analysis of the present progressive in French and English. Studies in Language, 37(4), 846-879.

Chen, K. (1997). English vs Chinese: World views and writing styles. TESOL Matters, 7, 1-13.

Fries, C.C. (1945). Teaching and learning English as a foreign language. Michigan: University of Michigan Press.

Hamel, N. (1925). A new universal French grammar; being an accurate system of French accidence and syntax, on a methodological plan (pp: 127). London: A. \& R. Spottiswoode, New-Street-Square.

Krzeszowski, T. P. (1990). Contrasting languages: The scope of contrastive linguistics. Walter de Gruyter.

Lado, R. (1957). Linguistics across culture: Applied linguistics for language teaching. Michigan: University of Michigan Press.

Lodge, R. A., Armstrong, N. Ellis, Y. M. L., \& Shelton, J.F. (1997). Exploring the French language (pp.146). London: John Wiley \& Sons. 
N'Gom, F. (1997). Contrastive phonological analysis of French and Mandinka (Master's thesis, University of Montana).

Odudigbo, M. E. (2014). Contrastive Analysis of French and Yoruba Language. Nigerian Defence Academy, Nigeria.

Payne, J.R. (2006). Noun phrases. In K. Brown (Ed.), Encyclopedia of language and linguistics (pp. 712-20). Amsterdam: Elsevier.

Rowlett, P. (2007). The syntax of French (pp.17). Cambridge University Press.

Salim, A. (1991). A Contrastive analysis between the French noun phrase and the English noun phrase (Doctoral dissertation, Southern Illinois University).

Siméus, M. A. (2017). French made simple: Synthesis of grammar. Bloomington: AuthorHouse.

Sallee, B. and Hebert, D. (2014). The everything essential French book: All you need to learn French in no time (p.155). Massachuets: Simon \& Schuster, Inc.

Tajareh, M. J. (2015). An overview of contrastive analysis hypothesis. Cumhuriyet Üniversitesi Fen-Edebiyat Fakültesi Fen Bilimleri Dergisi, 36(3), 1106-1113.

Thomas, J. (1983). Cross-cultural pragmatic failure. Applied Linguistics, 4, 91.

Vaillant, P. (2016). Noun phrases in mixed Martinican Creole and French: Evidence for an underspecified language model. Retrieved from https://hal.archives-ouvertes.fr/hal01451392.

Walid, M. C. M. (2012). English and French phonological systems: A contrastive study (Doctoral Dissertation, Université Badji Mokhtar-Annaba).

Weinreich, V. (1953). Languages in contact. New York: Linguistic Circles of NY. 